
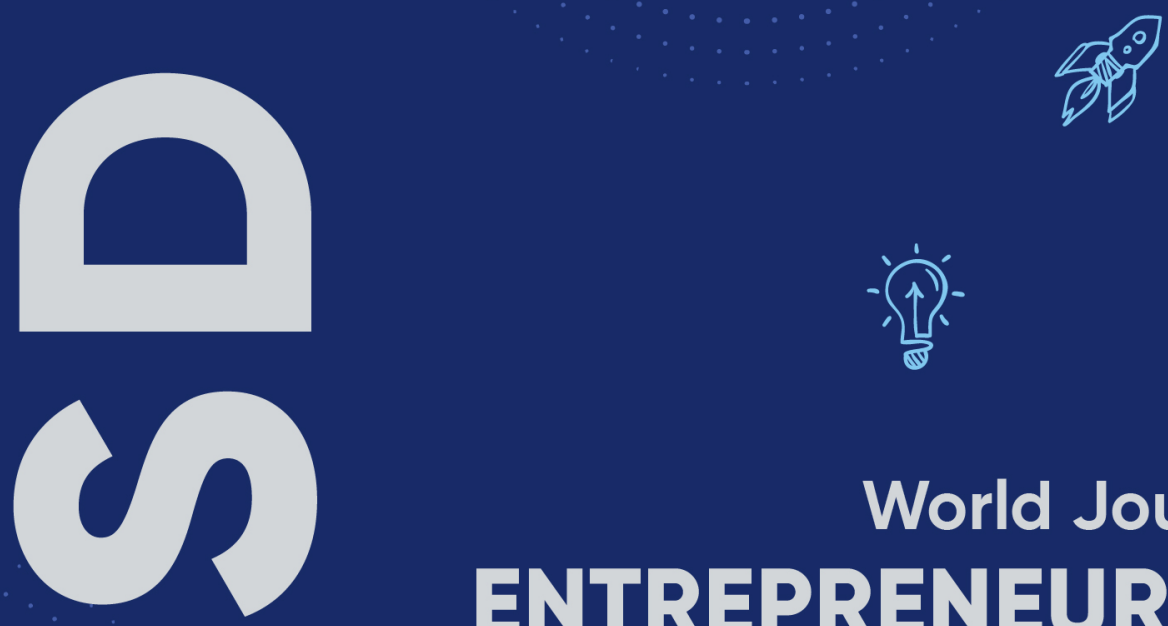

\title{
World Journal of
} ENTREPRENEURSHIP,

\section{MANAGEMENT AND SUSTAINABLE DEVELOPMENT}

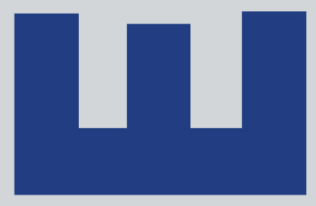

VOLUME $18 \bullet$ NUMBER $1 \bullet 2022$

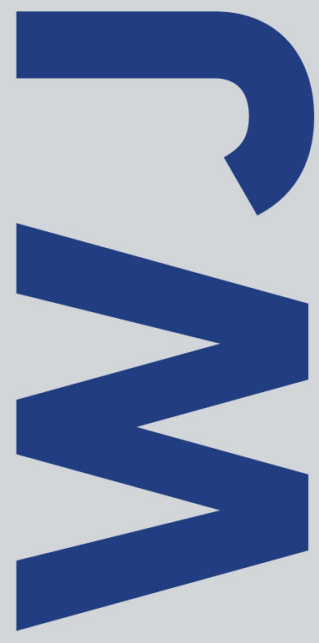

WJEMSD is published by the World Association for Sustainable

Development (WASD) in the United Kingdom (4 Issues per year) WJEMSD is abstracted and indexed by: Scopus; Thomson Reuters Emerging Sources Citation Index; INSPEC; ReadCube Discover; ABI/Inform (ProQuest); Cabell's Directory of Publishing Opportunities; British Library; and Crossref and is ranked by the Australian Business Deans Council (ABDC) and the Norwegian Centre for Research Data (NSD).

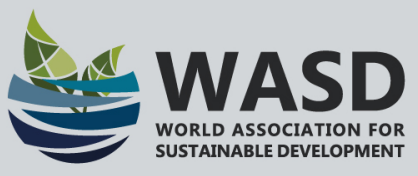
www.wasd.org.uk 

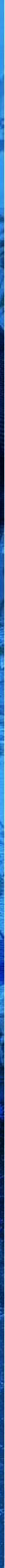

\section{Analysing Determinants in} Entreprenewnship Engagement in the Czech Republic: What is the Role of Caring Responsibilities? 


\section{Analysing Determinants Influencing Female Entrepreneurship Engagement in the Czech Republic: What is the Role of Caring Responsibilities?}

Dr. Ondřej Dvouletý

Department of Entrepreneurship

Prague University of Economics and Business

Czech Republic

Email: ondrej.dvoulety@vse.cz

Dr. Jarmila Duháček Šebestová

Department of Business Economics and Management, School of Business

Administration, Silesian University in Opava, Czech Republic

E-mail:sebestova@opf.slu.cz

Dr. Ivana Svobodová

Department of Entrepreneurship

Prague University of Economics and Business

Czech Republic

E-mail: ivana.svobodova@vse.cz

Dr. Blanka Habrmanová

Department of Entrepreneurship

Prague University of Economics and Business

Czech Republic

E-mail: blanka.habrmanova@vse.cz

Mrs. Jana Müllerová

Department of Entrepreneurship

Prague University of Economics and Business

Czech Republic

E-mail: jana.mullerova@vse.cz

CITATION: Dvouletý, O., Šebestová, J. D., Svobodová, I., Habrmanová, B. and Müllerová, J. (2022): Analysing Determinants Influencing Female Entrepreneurship Engagement in the Czech Republic: What is the Role of Caring Responsibilities?

World Journal of Entrepreneurship, Management and Sustainable Development, Vol 18, No. 1, pp. 1-19.

RECEIVED: 25 February 2021 / REVISED: 21 May 2021 / ACCEPTED: 24 May 2021 / PUBLISHED: 30 October 2021

COPYRIGHT: ๑ 2022 by all the authors of the article above. The article is published as an open access article by WASD under the terms and conditions of the Creative Commons Attribution (CC BY) license (https://creativecommons.org/licenses/by/4.0/). 


\begin{abstract}
Purpose: This research aimed to expand the current state-of-the-art on female entrepreneurs' characteristics from the perspective of a small European open economy - the Czech Republic. The study explores the individual determinants of female entrepreneurship engagement, and focuses mainly on the role of caring responsibilities.

Design/methodology/approach: The study relies on a secondary research sample of 7,204 employed or self-employed women participating in the 2017 edition of the European Union Labour Force Survey. Logistic regression analysis was used to determine differences between female employees, solo selfemployed women and females who create jobs.

Findings: The main conclusion is that there were no statistically significant differences between familyrelated variables (having a partner, number of children, marital status) and entrepreneurial engagement of Czech women. Other results showed that both types of female entrepreneurs work on average longer hours and have more years of experience.

Practical implications: Our study contributes to the ongoing discussion on managing business and having a partner and family by noting that women in today's society have learned how to balance their business-related and family-related duties.

Originality/value: The article extends the previous evidence on female entrepreneurship in the Czech Republic by delivering statistically robust empirical findings based on a large and representative dataset. Keywords: Female Entrepreneurship, Gender Entrepreneurship, Individual Determinants of Selfemployment
\end{abstract}

JEL codes: L26, L53, P42

\title{
Introduction
}

The United Nations' Sustainable Development Goals (SDGs, 2020) continuously promote gender equality in access to labour market opportunities. However, there are still significantly fewer women pursuing an entrepreneurship career pathway than men (Minniti and Naudé, 2010; Zeffane, 2015; Dean et al., 2019; Adeola et al., 2021; Salman Abdou, 2021). Female entrepreneurship is nowadays an established research discipline, being built on a multidisciplinary approach combining several existing theories (Loza, 2011), including the career theory (Bowen and Hisrich, 1986), the theory of discrimination (Fischer et al., 1993), or the feminist theory (Mirchandani, 1999). A very helpful review of the literature on women entrepreneurs was published by Yadav and Unni (2016); they summarised works published between 1980 and 2016 and highlighted the key milestones for female entrepreneurship research. These included the establishment of a topic-related journal, titled the International Journal of Gender and Entrepreneurship, in 2009 (Henry et al., 2020). Even the key entrepreneurship area journals have followed up with several special issues dedicated to female entrepreneurship, mostly aiming to capture differences between male and female entrepreneurs, their motivation, success and ways of doing business (Yadav and Unni, 2016).

Several scholars (De Bruin et al., 2006, 2007; Wasilczuk and Zieba, 2008; Leszczyński, 2016; Henry et al., 2016; Bernat et al., 2017) nevertheless argue that the previous research is still stuck in sex and gender issues, lacking comparative studies among women themselves and studies from countries and continents that have not yet received much attention. Moreover, Gundry et al. (2002) and Dvouletý and Orel (2020a) call for more studies investigating traditional determinants of female selfemployment. Others (Foley et al., 2018; Breen and Leung, 2020) question the traditional perception of women as wives and mothers and point out the sociological and cultural shifts in the current labour markets, where female entrepreneurs combine their caring and family-related duties with managing their own business. 
An example of a small European open economy, where female entrepreneurship research is still in the early stage, is the Czech Republic. The country has above-average entrepreneurial activity levels, and there are 2.5 times more men than women engaged in self-employment (Dvouletý, 2019, p.6). To illustrate the existing local state-of-the-art, we systematically searched for articles related to Czech female entrepreneurship in the Web of Science (Clarivate Analytics, 2021) and Scopus (Elsevier, 2021) databases. The search was conducted on 23 February 2021 , and the code returned ${ }^{1}$ only nine potentially relevant publications indexed in the Web of Science and ten publications in the Scopus database, not many at all.

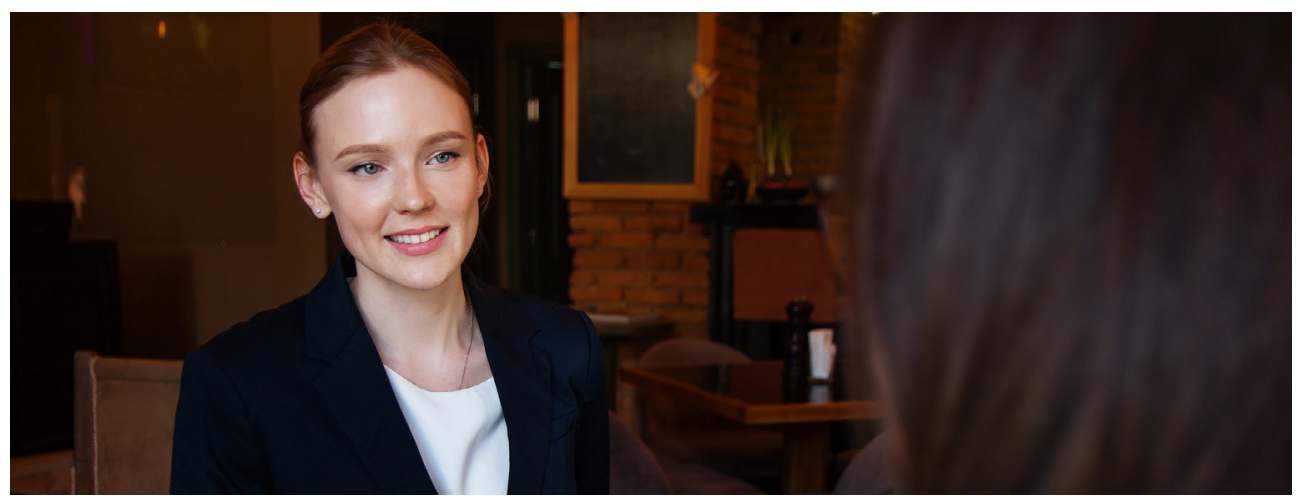

We provide a brief narrative overview of the previous works related to our country of interest the Czech Republic. In her work, Putnová (2003) stressed that Czech women often do not have career ambitions, and those who do have to face tough competition among men, while they still need to undertake the housework and caring responsibilities. However, Putnová (2003) further notes that as the Czech Republic moved away from its Soviet socialist times, the emancipation tendencies of Czech women began to grow, allowing them to start their own business and create their social identity. The family-career-business ties have also been the subject of later studies. Procházka (2016) conducted interviews with eight female entrepreneurs, who described how they balanced their business life with their families. The interviewed women, for example, mentioned time flexibility, allowing them to come from work early and leave the business aside to be with the family and children. Rašticová and Kolářová (2015) studied entrepreneurial opportunities among women aged 50 and 65+ years and highlight that not all women need to be engaged in the business full-time but could deal with smaller part-time projects, allowing them more time flexibility. Kř́žzová et al. (2014) conducted interviews among twelve entrepreneurial couples and provided insights into how couples share housework and business work. Although some interviewed women expected to share the housework equally at the time of business start-up, they became resigned to doing more housework than the men after a short time; however, the traditional heavy work was still done by men.

Lituchy et al. (2003) explored success criteria and main business-related problems among six Czech female entrepreneurs. The insights from interviews dedicated to success measures included the number of clients or the number of projects. The main problems faced by self-employed women included lack of human resource management skills, especially in terms of the employee-employer relationship. In their later work, Lituchy et al. (2004) stress the need to have a good mentor - a successful female 
entrepreneur who may help other women during the venture start-up stage. In a quantitative survey $(\mathrm{N}=248)$, Poczatkova and Kribikova (2016) found that most women would welcome having a mentor who might share experience and skills. The study aimed to show business-related problems faced by Czech women. Other challenges mentioned included a lack of start-up capital or balancing between business and family life. The lack of financial resources, financial insecurity, risks and stress were the main reasons preventing Czech women from starting their own business, as documented by Dvouletý (2020a).

We observe a lack of quantitative evidence on the characteristics of Czech women entrepreneurs. The only exception are studies by Holienka (2016a; 2016b), who analysed a pooled sample of economically active women from the Czech Republic, Hungary, Poland and Slovakia. The empirical results based on a sample from the Global Entrepreneurship Monitor covering years 2011-2014 found the importance of age, fear of failure, self-confidence and social capital distinguished female entrepreneurs from nonentrepreneurs. However, the study did not cover the established factors impacting entrepreneurial career pathways, such as education, experience or family-life situation (Simoes et al., 2016). In addition, it did not just cover the Czech Republic but pooled a sample of four countries.

Therefore, we build on the existing evidence and expand regional knowledge on female entrepreneurship by analysing characteristics that differentiate women entrepreneurs from those engaged in salaried positions. Building on previously published works focusing on Czech female entrepreneurship, we pay special attention to the impact of caring responsibilities on entrepreneurial engagement. Our study utilises secondary data about 7,204 employed or self-employed women who participated in the 2017 edition of the European Union Labour Force Survey. This sufficiently large and representative dataset allows us to deliver statistically robust empirical findings. Methodologically, we rely on the employment of logistic regression analysis; this was also used in similar studies, such as Singh et al. (2011), Noguera et al. (2013) or Cowling et al. (2019). Our study may also be interesting for the international readership because it provides insights into differences between solo self-employed women and those who employ other people (women who create jobs).

The article is structured into the following sections. The next part reviews the established literature on determinants of self-employment entry and justifies the tested hypothesis. Subsequently, the research sample and used variables are introduced. The fourth section offers insights into the results of multivariate analysis, and the last part of the article critically discusses the obtained results and provides directions for future research.

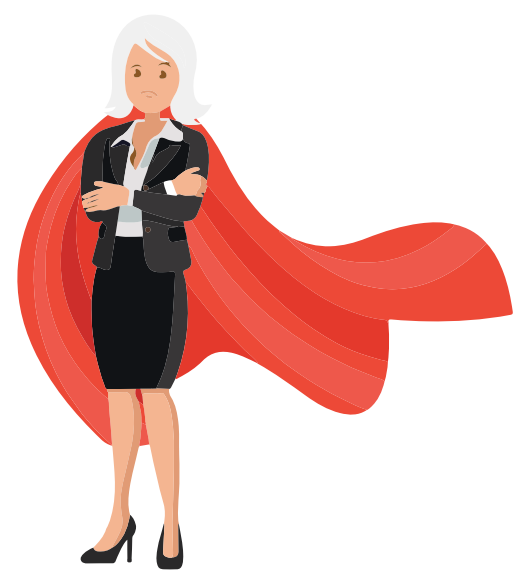




\section{Theoretical Background and Hypothesis Development}

This section aims to briefly review the up-to-date international literature studying factors influencing self-employment entry and introducing the central tested hypothesis. Cowling et al. (2019) recently conducted an extensive study covering several European Working Conditions Survey waves, including the time period between 1995 and 2015 . Over these 20 years, the authors confirm the empirical validity of the established individual determinants of entrepreneurship, such as age, education, experience accumulation, household and job-related characteristics, even though their magnitude has changed over the past two decades (Cowling et al., 2019).

To further explain the role of the earlier mentioned drivers of self-employment, we recall a systematic literature review article by Simoes et al. (2016). Simoes et al. (2016, p.786) explain that there is a changing relationship between entrepreneurship entry and age throughout the lifecycle. Generally, however, the age variable reflects the accumulation of various resources (human, financial and social capital) needed to establish a person's own business activity (Simoes et al., 2016).

According to Cooney (2021), being a part of an ethnic, religious or social minority group may significantly influence the propensity to become an entrepreneur based on the theoretical lenses of cultural theory or enclave theory. These approaches explain the processes and practices undertaken by minorities willing to earn income and become included in society (Simoes et al., 2016; Rahman et al., 2018).

As documented by previous research studies, accumulation of human capital, such as higher levels of education and accumulated years of experience, could be utilised in the formation of a new innovative and growing venture, indicating a positive relationship between human capital and entrepreneurship (Martin et al., 2013; Hanák and Grežo, 2020). Pursuing a self-employment journey is also more likely to be associated with some occupations and some industries than in others. Therefore, it is crucial to study the role of a particular occupation, industry and other job-related aspects, such as the number of working hours, when comparing entrepreneurs and non-entrepreneurs (Lee and Tuselmann, 2013; Bernat et al., 2016; Koster and Andersson, 2018).

Based on the regional review of the literature (Putnová, 2003; Poczatkova and Kribikova, 2016), we emphasise in this paper the women's family-career ties. Simoes et al. (2016, p.787) describe the household-career nexus of women with the help of Becker's specialisation hypothesis of the neoclassical theory of the family. Terrell and Troilo (2010) explain that this approach assumes that women specialise in taking care of children and increase their productivity in household-related jobs. As a result, scholars (Simoes et al., 2016; El Shoubaki and Stephan, 2018) assume a negative relationship between marriage, having children and self-employment engagement. Therefore, we state the central hypothesis for our research in the following way:

H1: Caring responsibilities for children prevent Czech women from pursuing an entrepreneurial career.

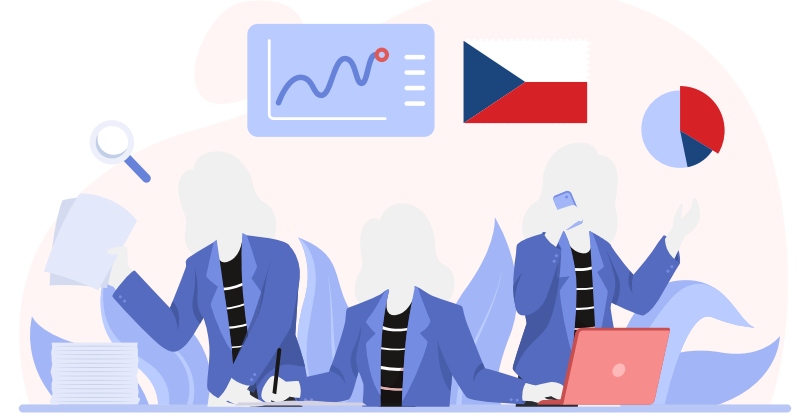




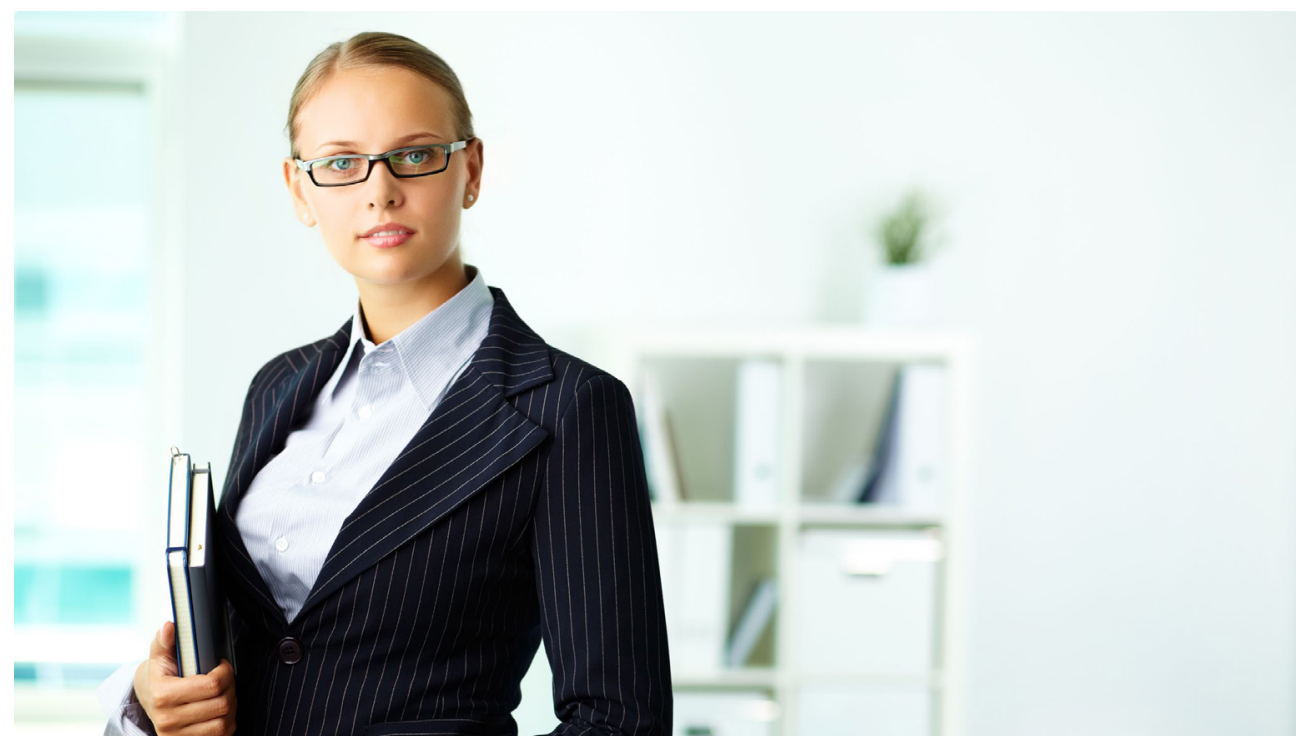

\section{Sample and Variables}

We work with a sample of economically active Czech women (those who are employed or selfemployed) that we extracted from the 2017 edition of the European Union Labour Force Survey (EU LFS) dataset. We work with the 2017 survey secondary data for two reasons. First, it is the largest European representative survey available for research purposes concerning the labour market. Second, the 2017 survey included specific questions related to self-employment, which is beneficial for our study focus on women entrepreneurs (Dvouletý, 2020a, 2020b). The EU LFS is maintained by the participating countries' national statistical offices and authorities (for more details about the survey, data collection and variables, see Eurostat, 2018, 2019, 2020). The EU LFS dataset allowed us to extract our target audience from the original dataset, so we worked only with women aged between 15 and 64 years who are either employed or self-employed. We further distinguish between those being solo self-employed and those who employ others as there is an increasing body of literature acknowledging differences between solo entrepreneurs and job creators (Burke et al., 2019; Boeri et al., 2020; Dvouletý and Orel, 2020b). We also know that including those pursuing multiple jobs in the sample could potentially bias our results (Campion et al., 2020), so we keep in our final sample only women having one primary job.

The final sample includes information about 7,204 employed or self-employed women (depending on the available variables ranging between 7,204 and 7,208 observations). The available determinants of women entrepreneurship include data about a respondent's age, nationality, education, years of experience, the usual number of working hours per week, skill-level classification of the profession, marital status, partner and children-related information, degree of urbanisation of the area of living, and industry classification. All these variables are explained in detail in Table 1. Table 2 provides summary statistics for the available variables. Initially, we may observe that the majority of women are employees as only $9.4 \%$ of the women are solo self-employed, and only $1.6 \%$ of economically active women create jobs for others. Such an observation is in line with the previously reported statistics on the development of Czech entrepreneurial activity, which, overall, is dominated by solo self-employed individuals (Hamplová et al., 2016; Dvouletý, 2019). 


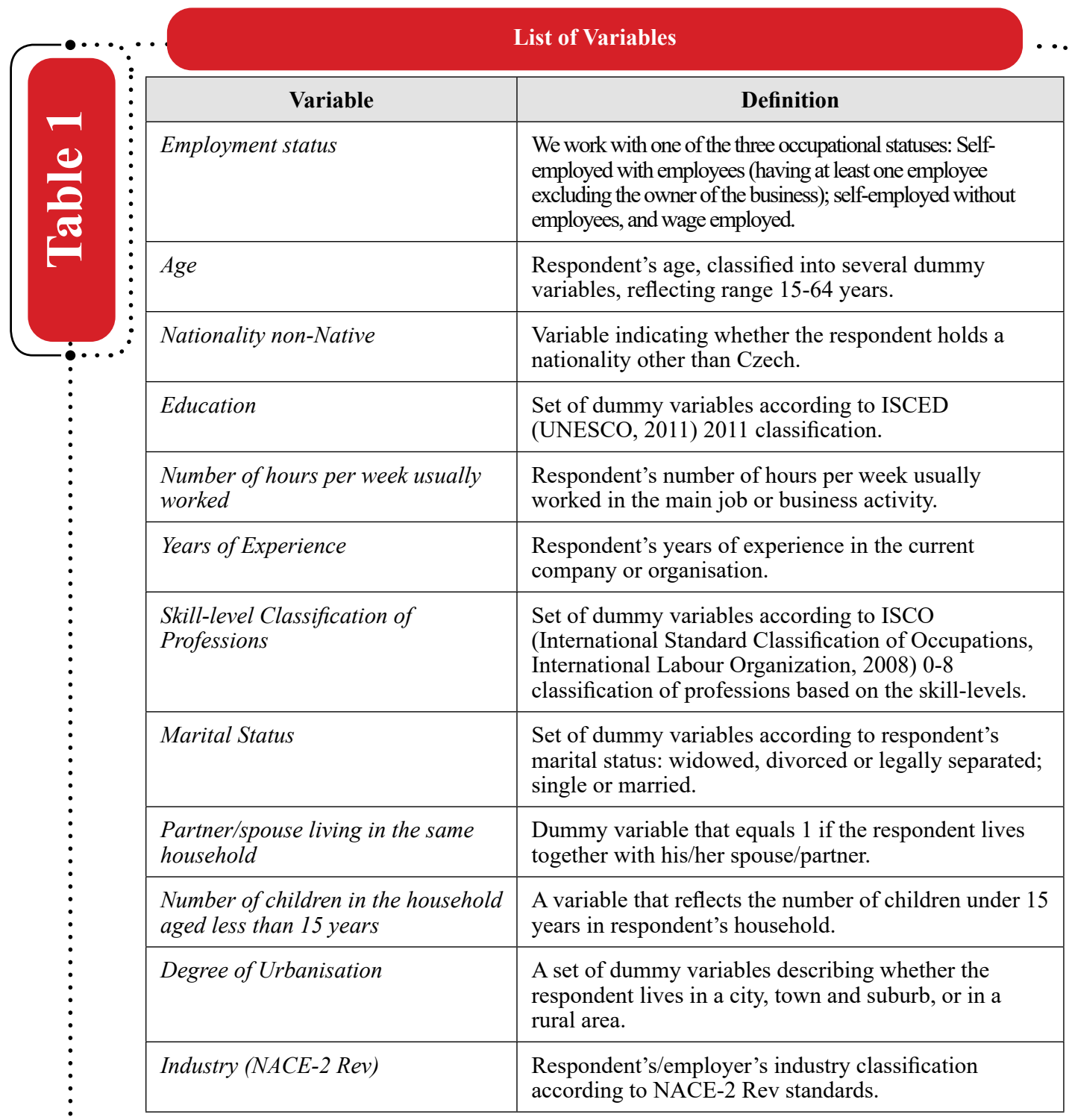

Source: Own elaboration based on the Labour Force Survey (LFS) ad hoc module 2017 data (Eurostat, 2018) 
Female Entrepreneurship in the Czech Republic $\quad>$

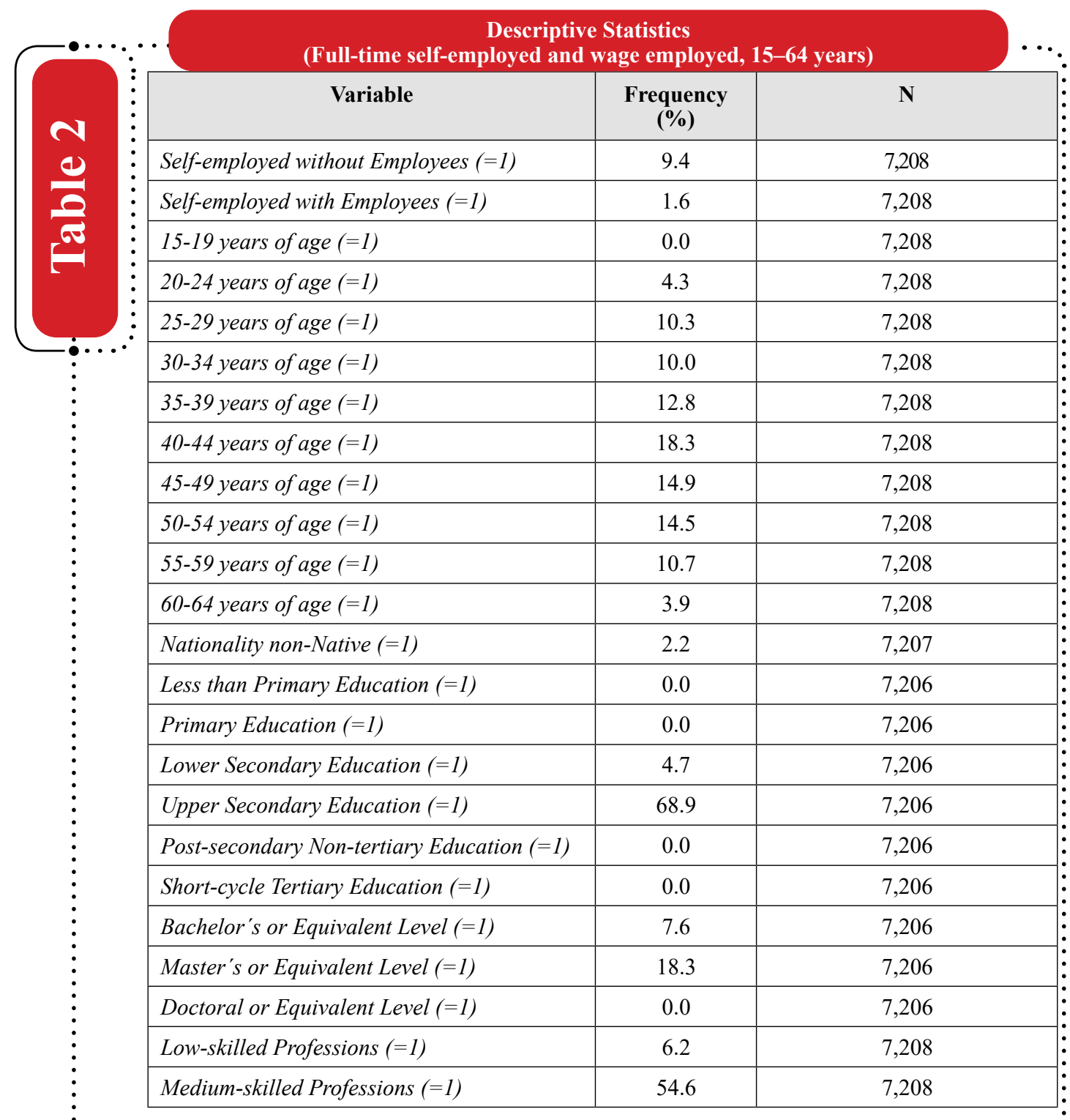

Cont. 


\begin{tabular}{|c|c|c|c|c|c|c|}
\hline & \multicolumn{5}{|c|}{$\begin{array}{l}\text { Descriptive Statistics } \\
\text { (Full-time self-employed and wage employed, 15-64 years) }\end{array}$} & \\
\hline & $\begin{array}{l}\text { High-skilled Professions without Managers } \\
(=1)\end{array}$ & 36.4 & \multicolumn{4}{|c|}{7,208} \\
\hline & High-skilled-Managers $(=1)$ & 2.9 & \multicolumn{4}{|c|}{7,208} \\
\hline & Widowed, divorced or legally separated $(=1)$ & 18.5 & \multicolumn{4}{|c|}{7,208} \\
\hline & Single $(=1)$ & 24.7 & \multicolumn{4}{|c|}{7,208} \\
\hline & Married $(=1)$ & 56.8 & \multicolumn{4}{|c|}{7,208} \\
\hline & $\begin{array}{l}\text { Partner/spouse living in the same household } \\
(=1)\end{array}$ & 70.0 & \multicolumn{4}{|c|}{7,208} \\
\hline & Cities (Densely populated area) $(=1)$ & 28.8 & \multicolumn{4}{|c|}{7,208} \\
\hline & $\begin{array}{l}\text { Towns and suburbs (Intermediate populated } \\
\text { area) (=1) }\end{array}$ & 34.9 & \multicolumn{4}{|c|}{7,208} \\
\hline : & Rural (Thinly populated area) $(=1)$ & 36.3 & \multicolumn{4}{|c|}{7,208} \\
\hline & Variable & Mean & SD & Min & Max & $\mathbf{N}$ \\
\hline & Number of hours per week usually worked & 40.6 & 4.2 & 20 & 80 & 7.204 \\
\hline & Years of Experience & 10.3 & 9.4 & 0 & 45 & 7,208 \\
\hline & $\begin{array}{l}\text { Number of children in the household aged } \\
\text { less than } 15 \text { years }\end{array}$ & 0.5 & 0.8 & 0 & 5 & 7,208 \\
\hline
\end{tabular}

Note: Post-stratification weights applied.

Source: Own elaboration based on the Labour Force Survey (LFS) ad hoc module 2017 data (Eurostat, 2018) :

\section{Empirical Analysis and Results}

The main aim of our research is to explore in which characteristics Czech women entrepreneurs are different from their wage-paid counterparts. Depending on the available characteristics (variables) introduced in the previous section, we seek to empirically observe how solo self-employed women and female entrepreneurs who create jobs differ from employees. To answer this research question, we utilise the empirical settings of a multivariate regression analysis; this has also been used by other scholars conducting similar studies (Singh et al., 2011; Noguera et al., 2013; Cowling et al., 2019). We estimate two separate logistic regression models with the help of STATA 14 software. First, we compare solo self-employed women with employees (in Model 1, Table 3), and in the second model, we compare job creators and dependent workers (in Model 2, Table 3). The dependent variable in both regression models equals 1 if the respondent is an entrepreneur (with or without employees); otherwise, it is 0 . The presented estimates are based on a weighted sample that accounts for the size of the Czech workforce; they include robust standard errors, and were found to be statistically significant. In addition, both models are controlled for industry differences by the inclusion of a set of dummies; these were also found to be statistically significant, but were not reported for parsimonious reasons. 
According to the results obtained, solo self-employed women differ from those wage employed in several aspects. They are on an average older, obtained higher levels of education, work more hours per week and have more years of experience. Looking at their professional status, they are most likely to work in highly skilled professions, however, not as managers. We further observe a positive relationship between being a citizen of a foreign country and solo self-employment. Quite surprisingly, variables related to caring responsibilities and family were found to be statistically insignificant; this also applies to the job creators group (Model 2). On the other hand, the differences between job creators and employees are not that straightforward, as most of the variables were not found to be statistically significant. It is logical that those women who manage businesses with employees are most likely to describe themselves as managers. There is a positive association between skill-level related to the profession and being a female job creator. As in the case of solo self-employed females, self-employed women with employees have, on average, more years of experience and they work longer hours.

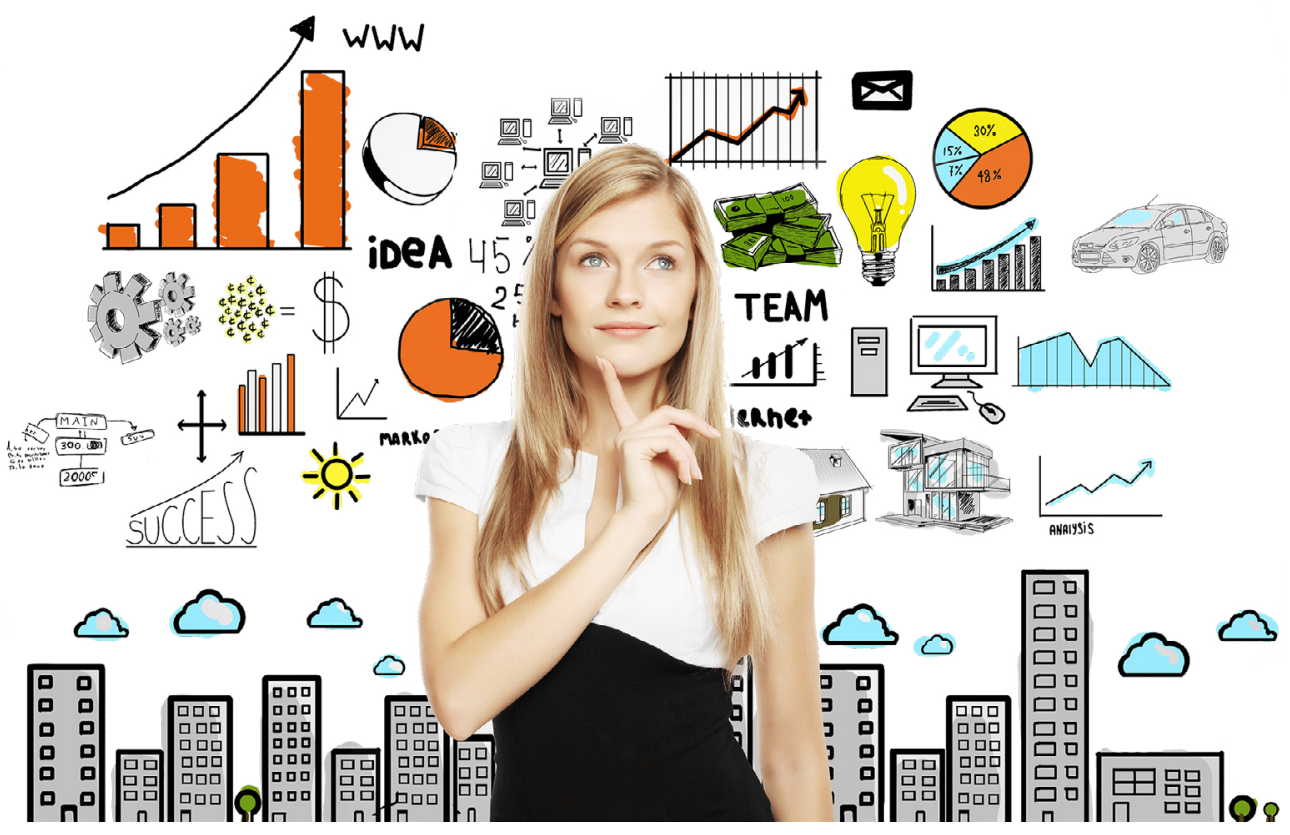


12 WJEMSD V18 N1 2022

Individual Determinants of Female Entrepreneurship in the Czech Republic

\begin{tabular}{|c|c|c|}
\hline Model number & Model (1) & Model (2) \\
\hline $\begin{array}{l}\text { Model number } \\
\text { Independent variables/ } \\
\text { Dependent variable }(=1) \text { : }\end{array}$ & $\begin{array}{c}\text { Self-employed without } \\
\text { Employees }\end{array}$ & $\begin{array}{c}\text { Self-employed with } \\
\text { Employees }\end{array}$ \\
\hline $20-24$ years of age & $\begin{array}{l}11.24 * * * \\
(0.823)\end{array}$ & 12.45 \\
\hline 25-29 years of age & $\begin{array}{l}12.36^{* * *} \\
(0.740)\end{array}$ & 13.61 \\
\hline $30-34$ years of age & $\begin{array}{l}12.49 * * * \\
(0.748)\end{array}$ & 13.58 \\
\hline 35-39 years of age & $\begin{array}{l}12.91 * * * \\
(0.756)\end{array}$ & 13.02 \\
\hline 40-44 years of age & $\begin{array}{l}12.98 * * * \\
(0.737)\end{array}$ & 14.37 \\
\hline 45-49 years of age & $\begin{array}{l}13.03 * * * \\
(0.745)\end{array}$ & 14.13 \\
\hline $50-54$ years of age & $\begin{array}{l}12.86^{* * *} \\
(0.747)\end{array}$ & 14.58 \\
\hline $55-59$ years of age & $\begin{array}{l}13.07 * * * \\
(0.750)\end{array}$ & 14.21 \\
\hline 60-64 years of age & $\begin{array}{l}13.25^{* * *} \\
(0.777)\end{array}$ & 15.23 \\
\hline Nationality non-Native & $\begin{array}{l}1.231 * * * \\
(0.371)\end{array}$ & $\begin{array}{c}0.160 \\
(0.874)\end{array}$ \\
\hline Lower Secondary Education & $\begin{array}{c}1.851^{*} \\
(0.880)\end{array}$ & $\begin{array}{l}-0.754 \\
(1.377)\end{array}$ \\
\hline Upper Secondary Education & $\begin{array}{c}1.940^{*} \\
(0.815)\end{array}$ & $\begin{array}{l}-1.483 \\
(1.227)\end{array}$ \\
\hline Short-cycle Tertiary Education & $\begin{array}{c}1.932 \\
(1.606)\end{array}$ & - \\
\hline Bachelor's or Equivalent Level & $\begin{array}{l}2.166^{* *} \\
(0.841)\end{array}$ & $\begin{array}{l}-0.999 \\
(1.249)\end{array}$ \\
\hline Master's or Equivalent Level & $\begin{array}{l}2.188^{* *} \\
(0.813)\end{array}$ & $\begin{array}{l}-0.109 \\
(1.213)\end{array}$ \\
\hline Medium-skilled Professions & $\begin{array}{l}0.865^{* *} \\
(0.333)\end{array}$ & $\begin{array}{l}14.68 * * * \\
(0.325)\end{array}$ \\
\hline $\begin{array}{l}\text { High-skilled Professions without } \\
\text { Managers }\end{array}$ & $\begin{array}{l}1.022^{* *} \\
(0.355)\end{array}$ & $\begin{array}{l}14.86^{* * * *} \\
(0.423)\end{array}$ \\
\hline High-skilled-Managers & $\begin{array}{l}21.396^{1} \\
(0.730)\end{array}$ & $\begin{array}{c}15.93 * * * \\
(0.568)\end{array}$ \\
\hline
\end{tabular}


Individual Determinants of Female Entrepreneurship in the Czech Republic

\begin{tabular}{|c|c|c|}
\hline Model number & Model (1) & Model (2) \\
\hline $\begin{array}{l}\text { Model number } \\
\text { Independent variables/ } \\
\text { Dependent variable }(=1) \text { : }\end{array}$ & $\begin{array}{l}\text { Self-employed without } \\
\text { Employees }\end{array}$ & $\begin{array}{l}\text { Self-employed with } \\
\text { Employees }\end{array}$ \\
\hline $\begin{array}{l}\text { Number of hours per week } \\
\text { usually worked }\end{array}$ & $\begin{array}{l}0.106^{* * *} \\
(0.0143)\end{array}$ & $\begin{array}{l}0.124 * * * \\
(0.0193)\end{array}$ \\
\hline Years of Experience & $\begin{array}{r}0.0220^{* *} \\
(0.00669) \\
\end{array}$ & $\begin{array}{c}0.0249^{*} \\
(0.0114) \\
\end{array}$ \\
\hline $\begin{array}{l}\text { Widowed, divorced or legally } \\
\text { separated }\end{array}$ & $\begin{array}{l}-0.142 \\
(0.220)\end{array}$ & $\begin{array}{c}-0.482 \\
(0.451)\end{array}$ \\
\hline Married & $\begin{array}{l}-0.261 \\
(0.222)\end{array}$ & $\begin{array}{r}0.0827 \\
(0.426)\end{array}$ \\
\hline $\begin{array}{l}\text { Partner/spouse living in the } \\
\text { same household }\end{array}$ & $\begin{array}{l}0.0468 \\
(0.175)\end{array}$ & $\begin{array}{c}0.172 \\
(0.406)\end{array}$ \\
\hline $\begin{array}{l}\text { Number of children in the } \\
\text { household aged less than } 15 \text { years }\end{array}$ & $\begin{array}{l}0.110 \\
(0.0909)\end{array}$ & $\begin{array}{c}0.247 \\
(0.177)\end{array}$ \\
\hline Cities (Densely populated area) & $\begin{array}{l}-0.226 \\
(0.142)\end{array}$ & $\begin{array}{l}-0.800 * \\
(0.353)\end{array}$ \\
\hline $\begin{array}{l}\text { Towns and suburbs (Intermediate } \\
\text { density area) }\end{array}$ & $\begin{array}{l}-0.0627 \\
(0.125)\end{array}$ & $\begin{array}{c}0.113 \\
(0.242)\end{array}$ \\
\hline Constant & $\begin{array}{c}-22.35 * * * \\
(1.311)\end{array}$ & -38.40 \\
\hline Industry dummies (NACE-2 Rev) & Yes & Yes \\
\hline Sample description & $\begin{array}{l}\text { Solo Self-employed } \\
\text { vs wage-employed }\end{array}$ & $\begin{array}{l}\text { Self-employed with } \\
\text { employees vs wage-employed }\end{array}$ \\
\hline Observations & 6,441 & 5,851 \\
\hline Prob $>$ chi2 & 0.000 & 0.000 \\
\hline Pseudo $R^{2}$ & 0.347 & 0.257 \\
\hline Akaike information criterion (AIC) & 842.0 & 283.3 \\
\hline Bayesian information criterion (BIC) & 1133.1 & 476.9 \\
\hline
\end{tabular}

Notes: Logistic regression results. Robust standard errors are in parentheses, stat. significance is reported as follows:

$+p<0.10, * p<0.05, * * p<0.01, * * * p<0.001$.

Reference groups for dummy variables: Age (15-19 years); Native of own Country; Primary Education; Low-skilled Professions; Rural area (Thinly populated area).

Source: STATA 14, own calculations based on the Labour Force Survey (LFS) ad-hoc module 2017 data (Eurostat, 2018) 


\section{Discussion and Conclusions}

This paper aimed to expand the current state of the knowledge regarding female entrepreneurship. Particularly, the study explored the characteristics of self-employed Czech females. Logistic regression analysis of 7,204 employed or self-employed women participating in the 2017 edition of the European Union Labour Force Survey revealed several aspects in which entrepreneurial women differ from fulltime employed females. Previous international (Yadav and Unni, 2016) and regional (Putnová, 2003; Poczatkova and Kribikova, 2016) research findings indicated strong family-career ties that may even prevent some women from starting their own company. However, the empirical results had not captured any statistically significant differences between family-related variables (having a partner, number of children, marital status) and entrepreneurial engagement of Czech women. Therefore, we were unable to support the validity of our hypothesis empirically. Based on this observation, we may only assume that a cultural shift in the Czech labour market has enabled women to live flexibly in families, have relationships and children, and run their own businesses, as suggested by some international scholars (Ajefu, 2019; Cowling et al., 2019). By this assumption, we do not say that it is easy to combine work and family life while being a mother and wife, as our data prove that self-employed women work on average more hours per week than those having a dependent job. This is in line with the previous research on the working hours of female entrepreneurs (Mattis, 2005). However, it is worth noting that longer working hours are still associated with a relatively high level of time flexibility, allowing women to maintain business- and family-related tasks and duties (Sappleton and Lourenco, 2016; Foley et al., 2018). In addition, Jeon and Ostrovsky (2019) provide emerging results showing that working hours of self-employed mothers were more uniformly distributed when compared with women having a salaried job.

Looking at the human capital theory (Simoes et al., 2016), our results show that self-employed Czech females, regardless of having employees or not, accumulated more years of experience and work in more demanding skill-level professions. Women who create jobs are most likely to work as managers (managing their employees and business), while solo self-employed women are most likely to work as highly skilled professionals. An interesting observation was that being a skilled solo self-employed professional is positively associated with a higher level of education; this reflects the accumulation of required knowledge needed for running an independent activity (Bögenhold, 2019; Burke and Cowling, 2020). Our analysis also shows that being a citizen of a foreign country is positively associated with solo self-employment. Therefore, migrant women coming to the Czech Republic might secure a job by starting an independent business activity. This finding is in line with the migrant entrepreneurship literature, although the effects of citizenship differ from country to country (Ram et al., 2017; Zybura et al., 2018).

The added value of the study for business practice implies that Czech women, wives and mothers no longer dominate only households and housework. If they have a good business idea, an entrepreneurial passion and the required skills, they may successfully combine their caring responsibilities with running and managing their own venture. In line with other studies (Terrell and Troilo, 2010; Byrne et al., 2019; Ajefu, 2019; Rugina, 2019), we recommend fostering female entrepreneurship through sharing experiences and establishing female entrepreneurship clubs, and empowerment by sharing stories of successful women entrepreneurs.

Finally, we also need to acknowledge that our results are based on one-year survey data only, so they do not have the rigour of a longitudinal study. Following Czech female entrepreneurs over time and studying their characteristics for several years in a row is undoubtedly a challenge left for future research. The ongoing studies might also challenge the relationship between the working hours of the female selfemployed, life satisfaction, and earnings. Notably, it might be interesting to explore the income ratios of partners living in the same household and see how they divide paid and non-paid (house) work. 


\section{References}

Adeola, O., Gyimah, P., Appiah, K.O. and Lussier, R.N. (2021): Can critical success factors of small businesses in emerging markets advance UN Sustainable Development Goals? World Journal of Entrepreneurship, Management and Sustainable Development, Vol. 17, No. 1, pp.85-105.

Ajefu, J.B. (2019): Does having children affect women's entrepreneurship decision? Evidence from Nigeria. Review of Economics of the Household, Vol. 17, No. 3, pp.843-860.

Bernat, L.F., Lambardi, G. and Palacios, P. (2017): Determinants of the entrepreneurial gender gap in Latin America. Small Business Economics, Vol. 48, No. 3, pp.727-752.

Boeri, T., Giupponi, G., Krueger, A.B. and Machin, S. (2020): Solo Self-Employment and Alternative Work Arrangements: A Cross-Country Perspective on the Changing Composition of Jobs. Journal of Economic Perspectives, Vol. 34, No. 1, pp.170-95.

Bögenhold, D. (2019): From Hybrid Entrepreneurs to Entrepreneurial Billionaires: Observations on the Socioeconomic Heterogeneity of Self-employment. American Behavioral Scientist, Vol. 63, No. 2, pp.129-146.

Bowen, D.D. and Hisrich, R.D. (1986): The female entrepreneur: A career development perspective. Academy of Management Review, Vol. 11, No. 2, pp.393-407.

Breen, R.H. and Leung, A. (2020): Choosing mothering and entrepreneurship: a relational career-life process. International Journal of Gender and Entrepreneurship, Vol. 12, No. 3, pp.253-271.

Burke, A. and Cowling, M. (2020): The role of freelancers in entrepreneurship and small business. Small Business Economics, Vol. 55, No. 2, pp.389-392.

Burke, A., Lyalkov, S., Millán, A., Millán, J.M. and van Stel, A. (2019): How do country R\&D change the allocation of self-employment across different types? Small Business Economics, Vol. 56, pp.695-721. DOI: https://doi.org/10.1007/s11187-019-00196-z.

Byrne, J., Fattoum, S. and Diaz Garcia, M.C. (2019): Role Models and Women Entrepreneurs: Entrepreneurial Superwoman Has Her Say. Journal of Small Business Management, Vol. 57, No. 1, pp.154-184.

Campion, E.D., Caza, B.B. and Moss, S.E. (2020): Multiple Jobholding: An Integrative Systematic Review and Future Research Agenda. Journal of Management, Vol. 46, No. 1, pp.165-191.

Clarivate Analytics (2021): Web of Science Database. Retrieved 23 February 2021, from https://www. webofknowledge.com/.

Cooney, T.M. (Ed.) (2021): The Palgrave Handbook of Minority Entrepreneurship. Springer Nature AG, Cham, Switzerland.

Cowling, M., Millán, J.M. and Yue, W. (2019): Two decades of European self-employment: is the answer to who becomes self-employed different over time and countries? Journal of Business Venturing Insights, Vol. 12, p.e00138.

De Bruin, A., Brush, C.G. and Welter, F. (2006): Introduction to the Special Issue: Towards Building Cumulative Knowledge on Women's Entrepreneurship. Entrepreneurship Theory and Practice, Vol. 30, No. 5, pp.585-593.

De Bruin, A., Brush, C.G. and Welter, F. (2007): Advancing a Framework for Coherent Research on Women's Entrepreneurship. Entrepreneurship theory and practice, Vol. 31, No. 3, pp.323-339.

Dean, H., Larsen, G., Ford, J. and Akram, M. (2019): Female Entrepreneurship and the Metanarrative of Economic Growth: A Critical Review of Underlying Assumptions. International Journal of Management Reviews, Vol. 21, No. 1, pp.24-49.

Dvouletý, O. (2019): Development of Entrepreneurial Activity in the Czech Republic Over the Years 2005-2017. Journal of Open Innovation: Technology, Market, and Complexity, Vol. 5, No. 3, p.38.

Dvouletý, O. (2020a): What Prevents Czech Women from Choosing Entrepreneurship as a Career Pathway? In Dvouletý, O, Lukeš, M. and Mísař, J. (Eds): Innovation Management, Entrepreneurship and Sustainability (IMES 2020), pp.133-139.

Dvouletý, O. (2020b): Classifying Self-employed persons using Segmentation Criteria available in the Labour Force Survey (LFS) Data, Journal of Business Venturing Insights, Vol. 14, p.e00199. 
Dvouletý, O. and Orel, M. (2020a): What drives Female Entrepreneurship in African developing countries? In Dobson, S., Jones, P., Agyapong, D. and Maas, G. (Eds): Enterprising Africa: Transformation through Entrepreneurship. Routledge.

Dvouletý, O. and Orel, M. (2020b): Determinants of solo and employer entrepreneurship in Visegrád countries: findings from the Czech Republic, Hungary, Poland and Slovakia. Journal of Enterprising Communities: People and Places in the Global Economy, Vol. 14, No. 3, pp.447-464. DOI: https://doi.org/10.1108/JEC-04-2020-0052.

El Shoubaki, A. and Stephan, M. (2018): The Life Partner and the Life Satisfaction of the Entrepreneur. Central European Business Review, Vol. 7, No. 3, pp.26-41.

Elsevier (2021): Scopus Database. Retrieved 23 February 2021, from https://www.scopus.com/search/ form.uri? display=basic.

Eurostat (2018): Labour Force Survey (LFS) ad-hoc module 2017 on the self-employed persons - Assessment report - 2018 edition. Available from: https://ec.europa.eu/eurostat/ documents/7870049/9439020/KS-39-18-011-EN-N.pdf/eabf6f91-01a1-4234-8a0a$43 \mathrm{c} 13 \mathrm{c} 3 \mathrm{bd} 920$.

Eurostat (2019): Labour Force Survey (LFS) Database User Guide. Available from: https://ec.europa. eu/eurostat/documents/1978984/6037342/EULFS-Database-UserGuide.pdf.

Eurostat (2020): Labour Force Survey. Available from: https://ec.europa.eu/eurostat/web/microdata/ european-union-labour-force-survey.

Fischer, E.M., Reuber, A.R. and Dyke, L.S. (1993): A theoretical overview and extension of research on sex, gender, and entrepreneurship. Journal of Business Venturing, Vol. 8, No. 2, pp.151-168.

Foley, M., Baird, M., Cooper, R. and Williamson, S. (2018): Is independence really an opportunity? The experience of entrepreneur-mothers. Journal of Small Business and Enterprise Development, Vol. 25, No. 2, pp.313-329. DOI: https://doi.org/10.1108/JSBED-10-2017-0306.

Gundry, L.K., Miriam, B.Y. and Posig, M. (2002): Contemporary perspectives on women's entrepreneurship: A review and strategic recommendations. Journal of Enterprising Culture, Vol. 10, No. 01, pp.67-86.

Hamplová, E., Kovárník, J. and Jedlicka, P. (2016): Analysis of Various Entrepreneurial Activities and their Development in the Czech Republic from 2008 to 2015. In Proceedings of the 13th International Scientific Conference European Financial System, Brno, Czech Republic (pp.227233).

Hanák, R. and Grežo, M. (2020): The effect of entrepreneurial experience on the quality of a business plan proposal in applying for angel investment. International Journal of Entrepreneurial Venturing, Vol. 12, No. 6, pp.617-647.

Henry, C., Foss, L. and Ahl, H. (2016): Gender and entrepreneurship research: A review of methodological approaches. International Small Business Journal, Vol. 34, No. 3, pp.217-241.

Henry, C., Foss, L. and Lewis, K.V. (2020): Guest editorial, International Journal of Gender and Entrepreneurship, Vol. 12, No. 1, pp.1-6.

Holienka, M., Jančovičová, Z. and Kovačičová, Z. (2016b): Drivers of women entrepreneurship in Visegrad countries: GEM evidence. Procedia-Social and Behavioral Sciences, Vol. 220, pp.124133.

Holienka, M., Jančovičová, Z. and Kovačičová, Z. (2016a): Women entrepreneurship in Visegrad region and its drivers. Acta Universitatis Agriculturae et Silviculturae Mendelianae Brunensis, Vol. 64, No. 6, pp.1899-1910.

International Labour Organization (2008): Skill-level Classification of Professions. Available from https://www.ilo.org/ilostat-files/Documents/description_OCU EN.pdf. Accessed on 21 January 2021.

Jeon, S.H. and Ostrovsky, Y. (2019): Balancing family and work: transition to self-employment among new mothers. Oxford Economic Papers, Vol. 71, No. 1, pp.47-72. 
Koster, S. and Andersson, M. (2018): When is your experience valuable? Occupation-industry transitions and self-employment success. Journal of Evolutionary Economics, Vol. 28, No. 2, pp.265-286.

Kř́žzová, A., Jurik, N. and Dlouhá, M. (2014): The divisions of labour and responsibilities in business and home among women and men copreneurs in the Czech Republic. In Lewis, K., Watson, J., Henry, C. and Gatewood, E. (Eds): Women's Entrepreneurship in the 21 st Century: An International Multi-Level Research Analysis (pp.258-277). Edward Elgar Publishing.

Lee, R. and Tuselmann, H. (2013): Entrepreneurship, occupational division and social capital differentials. Journal of Small Business and Enterprise Development, Vol. 20, No. 3, pp.661-680.

Leszczyński, D. (2016): Exploration of key success factors that influence business performance: The experiences of women micro-entrepreneurs from Mazovia Voivodeship of Poland. International Journal of Management and Economics, Vol. 51, No. 1, pp.63-89.

Lituchy, T.R. and Reavley, M.A. (2004): Women entrepreneurs: A comparison of international small business owners in Poland and the Czech Republic. Journal of International Entrepreneurship, Vol. 2, No. 1, pp.61-87.

Lituchy, T.R., Bryer, P. and Reavley, M.A. (2003): Small Business in the Czech Republic and Japan: Successes and Challenges for Women Entrepreneurs. In Etemad, H. and Wright, R. (Eds): Globalisation and Entrepreneurship: Policy and strategy perspectives, pp.152-179, Edward Elgar Publishing.

Loza, E. (2011): Female Entrepreneurship Theory: A Multidisciplinary Review of Resources. Journal of Women's Entrepreneurship and Education, Nos 1-2, pp.26-64.

Martin, B.C., McNally, J.J. and Kay, M.J. (2013): Examining the formation of human capital in entrepreneurship: A meta-analysis of entrepreneurship education outcomes. Journal of Business Venturing, Vol. 28, No. 2, pp.211-224.

Mattis, M.C. (2005): 'I'm out of here': women leaving companies in the USA to start their own businesses. In Fielden, S.L. and Davidson, M.J. (Eds): International Handbook of Women and Small Business Entrepreneurship. Cheltenham: Edward Elgar, pp.221-235.

Minniti, M. and Naudé, W. (2010): Introduction: What Do We Know About The Patterns and Determinants of Female Entrepreneurship Across Countries? The European Journal of Development Research, Vol. 22, No. 3, pp.277-293. DOI: https://doi.org/10.1057/ejdr.2010.17.

Mirchandani, K. (1999): Feminist Insight on Gendered Work: New Directions in Research on Women and Entrepreneurship. Gender, Work \& Organisation, Vol. 6, No. 4, pp.224-235.

Noguera, M., Alvarez, C. and Urbano, D. (2013): Socio-cultural factors and female entrepreneurship. International Entrepreneurship and Management Journal, Vol. 9, No. 2, pp.183-197.

Poczatkova, B. and Kribikova, P. (2016): Status of woman-entrepreneur in Czech Republic. Aktual'ni Problemy Ekonomiky=Actual Problems in Economics, Vol. 176, No. 2, pp.208-214.

Procházka, D.A. (2016): Women entrepreneurs in regional development (behaviour in local environment). Proceedings of the International Scientific Conference on Region in the Development of the Society, pp.751-754.

Putnová, A. (2003): Czech women's entrepreneurship. EJBO-Electronic Journal of Business Ethics and Organization Studies, Vol. 8, No. 1, pp.1-6.

Rahman, M.Z., Ullah, F. and Thompson, P. (2018): Challenges and issues facing ethnic minority small business owners: The Scottish experience. The International Journal of Entrepreneurship and Innovation, Vol. 19, No. 3, pp.177-193.

Ram, M., Jones, T. and Villares-Varela, M. (2017): Migrant entrepreneurship: Reflections on research and practice. International Small Business Journal, Vol. 35, No. 1, pp.3-18.

Rašticová, M. and Kolářová, I. (2015): Employment of Women and Female Entrepreneurship in Age Cohorts 50-64 and 65+ and comparison with EU. In Slavíčková, P. and Tomčík, J. (Eds): Proceedings of the International Scientific Conference on Knowledge for Market Use - Women in Business in the Past and Present, pp.809-824. 
Rugina, S. (2019): Female entrepreneurship in the Baltics: formal and informal context. International Journal of Gender and Entrepreneurship, Vol. 11, No. 1, pp.58-74. DOI: https://doi.org/10.1108/ IJGE-05-2018-0055.

Salman Abdou, D.M. (2021): Future of Egyptian female entrepreneurs post COVID-19. World Journal of Entrepreneurship, Management and Sustainable Development, forthcoming, DOI: https://doi. org/10.1108/WJEMSD-07-2020-0094.

Sappleton, N. and Lourenço, F. (2016): Work satisfaction of the self-employed: The roles of work autonomy, working hours, gender and sector of self-employment. The International Journal of Entrepreneurship and Innovation, Vol. 17, No. 2, pp.89-99.

Simoes, N., Crespo, N. and Moreira, S.B. (2016): Individual determinants of self-employment entry: What do we really know? Journal of Economic Surveys, Vol. 30, No. 4, pp.783-806.

Singh, S., Simpson, R., Mordi, C. and Okafor, C. (2011): Motivation to become an entrepreneur: a study of Nigerian women's decisions. African Journal of Economic and Management Studies, Vol. 2, No. 2, pp.202-219.

Terrell, K. and Troilo, M. (2010): Values and female entrepreneurship. International Journal of Gender andEntrepreneurship, Vol.2, No.3,pp.260-286.DOI:https://doi.org/10.1108/17566261011079242.

United Nations Development Programme (UNDP) (2020): Sustainable Development Goals: Gender equality. Available from https://www.undp.org/content/undp/en/home/sustainable-developmentgoals/goal-5-gender-equality.html. Accessed on 21 January 2021.

United Nations Educational, Scientific and Cultural Organization (UNESCO) (2011): International Standard Classification of Education: ISCED 2011 Classification. Available from http://uis. unesco.org/sites/default/files/documents/international-standard-classification-of-education-isced2011-en.pdf. Accessed on 21 January 2021.

Wasilczuk, J. and Zieba, K. (2008): Female Entrepreneurship in Transitional Economies: the Case of Poland. Journal of Small Business \& Entrepreneurship, Vol. 21, No. 2, pp.153-169.

Yadav, V. and Unni, J. (2016): Women entrepreneurship: research review and future directions. Journal of Global Entrepreneurship Research, Vol. 6, No. 1, pp.1-18.

Zeffane, R. (2015): Trust, personality, risk taking and entrepreneurship: Exploring gender differences among nascent and actual entrepreneurs in the United Arab Emirates. World Journal of Entrepreneurship, Management and Sustainable Development, Vol. 11, No. 3, pp.191-209. DOI: https://doi.org/10.1108/WJEMSD-08-2014-0025.

Zybura, N., Schilling, K., Philipp, R. and Woywode, M. (2018): Female Migrant Entrepreneurship in Germany: Determinants and Recent Developments. In Birkner S., Ettl K., Welter F. and Ebbers I. (Eds): Women's Entrepreneurship in Europe: Multidimensional research and case study insights. FGF Studies in Small Business and Entrepreneurship. Springer, Cham.

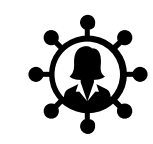




\section{Biography}

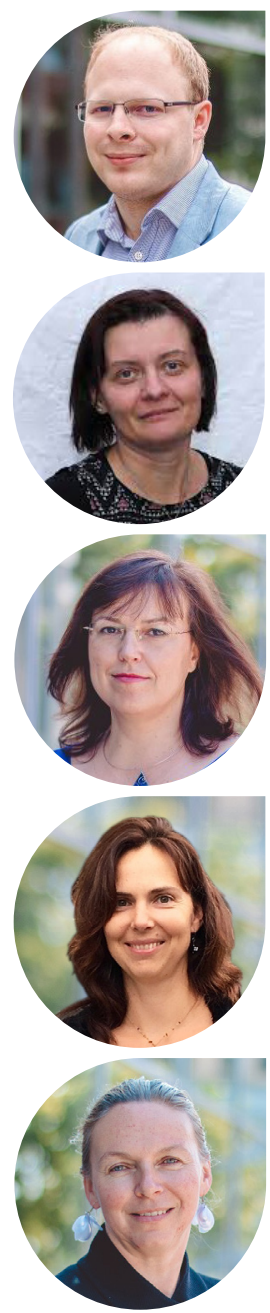

Ondřej Dvouletý is an Associate Professor at the Department of Entrepreneurship, Prague University of Economics and Business. His research focuses on the heterogeneity of self-employment, entrepreneurship and SME policy evaluation and entrepreneurial economics. He is Associate Editor of the Journal of Small Business Management, Journal of Entrepreneurship in Emerging Economies, and Central European Business Review. Ondřej is also the Editor of the annual Innovation Management, Entrepreneurship and Sustainability (IMES) conference.

Jarmila Duháček Šebestová is an Associate Professor at the Department of Business Economics and Management, Silesian University in Opava. Her research focuses on business economics, social entrepreneurship and social innovation. Jarmila is also the Programme Chair of the biannual Decision making for Small and Medium-Sized Enterprises (DEMSME) conference.

Ivana Svobodová is an Assistant Professor at the Department of Entrepreneurship, Prague University of Economics and Business. She is interested mainly in crowdfunding and business model innovation.

Blanka Habrmanová is an Assistant Professor at the Department of Entrepreneurship, Prague University of Economics and Business. She is interested mainly in entrepreneurial exits and in the transgenerational transmissions of family businesses.

Jana Müllerová is an Assistant Professor at the Department of Entrepreneurship, Prague University of Economics and Business. She is interested mainly in social entrepreneurship and business ethics.

\section{Acknowledgements}

This work was supported by the Internal Grant Agency of the Faculty of Business Administration, Prague University of Economics and Business under no. IP300040. 